Original Research Paper

\title{
Early Study on Embryogenesis O.woworae at Different Salinities
}

\author{
Fani Savitri Agatha $^{1}$, Mustahal ${ }^{1 *}$, Mas Bayu Syamsunarno ${ }^{1}$, Muh. Herjayanto ${ }^{1}$ \\ ${ }^{1}$ Program Studi Ilmu Perikanan, Universitas Sultan Ageng Tirtayasa, Kota Serang, Indonesia
}

\author{
Article History \\ Received : March $23^{\text {th }}, 2021$ \\ Revised : April 07 $7^{\text {th }}, 2021$ \\ Accepted : April 21 th 2021 \\ Published : May $03^{\text {th }}, 2021$ \\ *Corresponding Author: \\ Mustahal, \\ Program Studi Ilmu Perikanan, \\ Universitas Sultan Ageng \\ Tirtayasa, Kota Serang, \\ Indonesia \\ Email: mustahal13@gmail.com
}

\begin{abstract}
Oryzias woworae is an endemic fish of Sulawesi. This endemic fish naturally had faced endangered illegal and unlawful capture, therefore it is needed to be protected and conserved by a cultivation system. This research aims to provide basic information related to the cultivation of $O$. woworae to know the optimum salinity of hatching media and its influence on the hatchability of eggs and the length of time hatching $O$. woworae. This research was conducted using experimental methods and presented descriptively. The treatment used in this study is $0 \mathrm{ppt}, 2-4 \mathrm{pt}, 6-8 \mathrm{ppt}, 10-12 \mathrm{ppt}$. The results showed that $O$. woworae eggs can hatch in salinity 0 ppt until 10-12 ppt and the best salinity for the length of hatching time is treatment of 2-4 ppt which is 7 th day 14 hours 20 minutes. Treatment 0 ppt, 2-4 ppt and 6-8 ppt can reach 100\%. This can be concluded that the optimum salinity of the hatching rate of Oryzias woworae until 6-8 ppt, but in treatment $10-12$ ppt hatchability only gets $80 \%$ as some embryos become shrinking. Hatchability per day shows the treatment of $2-4 \mathrm{ppt}$ is the best treatment, on the $7^{\text {th }}$ day as much as $40 \%$ and on the $8^{\text {th }}$ day as much as $40 \%$. The optimal salinity for hatching $O$. woworae eggs is $2-4 \mathrm{ppt}$ treatment, salinity that can expedite the length of hatching time and produce hatching rate by $100 \%$.
\end{abstract}

Keywords: Embryogenesis, Endemic Sulawesi, Ornamental Fish, Oryzias Woworae, Salinity

\section{Pendahuluan}

Indonesia memiliki ricefish dari genus Oryzias sebanyak 18 spesies (Parenti, 2008, Hadiaty, 2018, Mandagi et al., 2018). Sebanyak satu spesies, merupakan endemik Jawa Barat yaitu Oryzias hubbsi (Roberts, 1998), kemudian spesies O. javanicus yang memiliki persebaran luas yaitu di Sumatera, Jawa, Kalimantan, Bali, Lombok dan Sulawesi (Parenti, 2008). 16 spesies lainnya ikan padi yaitu adalah endemik di danau, sungai atau kolam mata air di Pulau Sulawesi (Parenti, 2008, Dahruddin, 2012, Hadiaty, 2018, Mandagi et al., 2018).

Beberapa spesies Oryzias endemik Sulawesi memiliki warna yang indah dan telah diperdagangkan sebagai ikan hias. Hal ini menyebabkan spesies ricefish endemik dari perairan Sulawesi memiliki potensi yang cukup besar dan memiliki peluang untuk dikembangkan sebagai ikan budidaya (Fahmi et al., 2014). Salah satu spesies tersebut adalah O.woworae yang memiliki habitat di perairan tawar Pulau Muna, Sulawesi Tenggara. $O$. woworae merupakan salah satu jenis ricefish yang memiliki warna biru keperakan dan terdapat garis merah-oranye pada sirip ekor (Parenti et al., 2013). Ciri khusus ikan $O$. woworae lainnya adalah memiliki mata di atas posisi hidung dengan ukuran yang cukup besar (Fahmi et al., 2014). Ikan ini memiliki potensi yang baik jika dilihat dari segi harga. Berdasarkan hasil survei, harga ikan O.woworae dipasar Indonesia adalah Rp.2.750 - Rp.35.000 per ekor dan harga ikan O.woworae di pasar internasional mencapai US\$2.7 - US\$9.9 atau jika dikonservasikan ke dalam rupiah adalah Rp.38.961 - Rp.142.857 per ekor (Jika dikonversikan dengan kurs dollar saat ini Rp.14.430 per dollar).

Informasi tentang budidaya O.woworae belum tersedia. Ikan $O$. woworae yang dipasarkan masih mengandalkan hasil 
tangkapan alam. Perlu adanya pengembangan budidaya $O$. woworae sehinga ikan ini terjaga dari eksploitasi berlebih. Ketersediaan benih sering menjadi kendala dalam proses budidaya ikan karena lamanya waktu penetasan telur (Mubarokah et al., 2014). Kunci awal keberhasilan kegiatan budidaya adalah pembenihan dan ketersediaan benih (Hutagalung et al., 2017). Pada kegiatan pembenihan, stadia awal kehidupan ikan yaitu saat embrio merupakan fase yang sangat penting diperhatikan. Lingkungan yang tidak sesuai akan menyebabkan embrio mati, sehingga menyebabkan rendahnya tingkat pada penetasan telur (Effendi, 2012). Faktor lingkungan yang berpengaruh terhadap penetasan adalah suhu, $\mathrm{DO}, \mathrm{pH}$, intensitas cahaya dan salinitas (Hutagalung et al., 2017). Rekayasa lingkungan adalah salah satu cara untuk mempercepat penetasan telur. Pengaturan salinitas media inkubasi telur merupakan salah satu rekayasa lingkungan untuk penetasan telur (Mubarokah et al., 2014).

Salinitas adalah ukuran konsentrasi ionion yang terlarut dalam air (Mustofa, 2020). Salinitas media merupakan salah satu faktor lingkungan yang mempengaruhi derajat tetas telur (Hadid et al., 2014, Mubarokah et al., 2014), lama waktu penetasan telur dan kualitas telur. Tekanan osmotik dalam telur ikan akan dipengaruhi oleh salinitas, kondisi salinitas yang tidak ideal dengan tekanan osmotik telurnya maka telur membutuhkan energi yang relatif besar untuk mempertahankan osmotik telurnya (Mubarokah et al., 2014). Kondisi salinitas yang mendekati isoosmotik energi, pendekatan konsentrasi ion dan lingkungan dalam osmoregulasi akan menjadi minimal yang dapat memaksimalkan pertumbuhan pada embrio dan mempertahankan kelangsungan hidup telur selama inkubasi (Heltonika, 2014).

Kajian salinitas media inkubasi yang optimum untuk ikan O.woworae belum pernah dilakukan. Sehingga perlu dilakukan studi awal untuk menentukan salinitas optimum terhadap embriogenesis, lama waktu penetasan, derajat tetas telur dan kualitas air bagi ikan $O$. woworae.

\section{Bahan dan Metode}

\section{Waktu dan Tempat}

Penelitian telah dilakukan pada bulan Januari-Februari 2021 di Laboratorium Budidaya Perairan, Program Studi Ilmu Perikanan, Fakultas Pertanian, Universitas Sultan Ageng Tirtayasa. Induk ikan O.woworae yang digunakan berasal dari penjual ikan hias di Depok, Jawa Barat.

Parameter yang diamati adalah embriogenesis, lama waktu penetasan dan derajat tetas telur serta kualitas air. Hasil disampaikan secara deskriptif dan ditampilkan berupa gambar dan tabel.

\section{Adaptasi Ikan dan Pemijahan}

Induk $O$. woworae yang matang gonad berusia 3-4 bulan dengan ukuran 2-3 $\mathrm{cm}$. Induk jantan $O$. woworae memiliki ciri tubuh, warna perak kebiruan yang menyala dan sirip dada merah terang, bergerak aktif dan ketika pagi hari jantan memiliki warna tubuhnya cenderung menghitam. Sedangkan pada induk betina O.woworae yang matang gonad memiliki perut yang membuncit dengan warna tidak mencolok seperti jantan.

Transportasi ikan $O$. woworae dilakukan dengan pengangkutan sistem basah, sistem ini dianggap efisien dan mendapatkan survival rate yang lebih tinggi dibandingkan sistem pengangkutan kering dan sistem pengangkutan semi basah (Nani et al., 2015). Adaptasi induk ikan setelah proses perjalanan transportasi harus diperhatikan, ikan cenderung mengalami stres saat diperjalanan. Ikan $O$. woworae merupakan jenis ikan yang mudah terserang jamur. Ikan dimasukkan pada aquarium 70x30x35 cm. Pemberian methylen blue pada media air dapat mencegah tumbuhnya jamur pada media. Pemisahan antara ikan jantan dan betina dilakukan supaya performa ikan dan telur tetap baik saat penelitian. Penyiponan perlu dilakukan setiap hari agar media air tetap terjaga kualitasnya.

Seleksi induk ikan dilakukan selama 3-4 hari, induk ikan dipilih dan dipisahkan pada aquarium 30x30x30 $\mathrm{cm}$. Pemijahan ikan dilakukan dengan media air tawar. Induk ikan $O$. woworae yang digunakan pada penelitian ini sebanyak 96 ekor. Pemijahan O. woworae ini dilakukan secara massal dengan rasio 2 ekor betina dan 1 ekor jantan yang dibagi pada 4 aquarium. Induk ikan dilakukan pemberian pakan berupa Artemia sp. dan Moina sp. pada 
pukul 06.00, 12.00 dan pukul 17.00 WIB dengan metode pemberian pakan at satiation (Herjayanto et al., 2017).

\section{Pengamatan Embriogenesis}

Substrat dimasukkan kedalam akuarium pemijahan. Setelah pemberian pakan pukul 06.00 WIB. Substrat dibuat dari tali rafia. Substrat ini dianggap lebih efisien untuk pemijahan ikan karena ekonomis, mudah dibersihkan dan tidak akan mengotori aquarium pemijahan dan wadah penetasan (Herjayanto et al., 2016). Pada pemijahan ikan $O$. woworae suhu yang digunakan tidak diberikan perlakuan dan mengikuti suhu lingkungan yaitu pada kisaran $24-28^{\circ} \mathrm{C}$. Pengukuran kualitas air dilakukan untuk mengetahui parameter berupa DO (Dissolved oxygen), $\mathrm{pH}$ dan suhu didalam akuarium penetasan dan wadah pemijahan.

Penetasan telur dilakukan di wadah toples 15 liter. Perlakuan yang digunakan yaitu 0 ppt, 24 ppt, 6-8 ppt, 10-12 ppt. Koleksi telur dilakukan dengan memindahkan telur dari substrat pemijahan ke substrat penetasan. Koleksi telur dilakukan secara cepat supaya telur tidak rusak dan teliti supaya jumlah telur yang dimasukkan kedalam perlakuan sesuai. Pengukuran kualitas air dilakukan setiap hari berupa $\mathrm{DO}, \mathrm{pH}$ dan suhu. Pengukuran salinitas dilakukan 2 kali dalam sehari. Salinitas didapatkan dari pengenceran air tawar dengan garam ikan. Salinitas dipertahankan pada setiap perlakuan sesuai dengan rentangan salinitas yang digunakan. Dilakukan penambahan air bersalinitas 35 ppt jika salinitas dalam wadah mengalami penurunan salinitas dan penambahan air jika salinitas dalam wadah mengalami kenaikan salinitas. Pengamatan embriogenesis dilakukan dengan menggunakan mikroskop cahaya pembesaran 40x. Pengamatan dilakukan setiap 10 menit pada fase cleavage, setiap 30 menit pada fase morula, setiap 2 jam pada fase blastula dan fase gastrula dan setiap 6 jam pada fase organogenesis. Suhu yang digunakan untuk inkubasi telur adalah $29-30^{\circ} \mathrm{C}$.

\section{Hasil dan Pembahasan}

\section{Embriogenesis}

Ikan O. woworae merupakan jenis ikan partial spawning dan mampu bertelur setiap hari.
Pemijahan terjadi pada pagi sampai siang hari. Telur saling menempel satu sama lain di lubang genital betina (Gambar 1a), karena attaching fillament (Gambar 4f) masih menempel pada lubang genital betina. Betina akan membawa telurnya beberapa saat sebelum ditempelkan ke substrat. Pengambilan substrat dari wadah pemijahan harus dilakukan cepat, karena induk ikan $O$. woworae cenderung memakan telur.

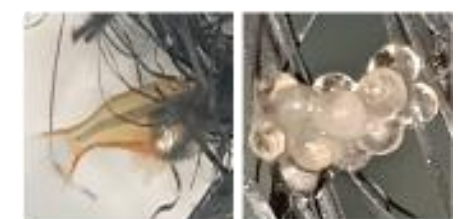

(a) (b)
Gambar 1. (a) telur dibawa oleh betina dan

(b) kelompok telur

Telur ikan $O$. woworae yang dibuahi berbentuk bulat, terlihat transparan dan butiran minyak terlihat dengan mata telanjang (Gambar 1b). Ukuran telur 1,41-1,48 mm (1,43 $\pm 0,06 \mathrm{~mm})$ dengan warna telur keoranyean. Telur ikan ini memiliki tipe telur telolesital, yaitu kuning telur terletak pada satu sisi atau kutub (Sumarmin, 2016). Telur yang tidak dibuahi (Gambar 4a) sangat mudah untuk pecah dan sangat sulit untuk melihat ruang perivitelline, yaitu ruang antara korion dan kuning telur (Kinoshita et al., 2009). Warna telur yang tidak dibuahi cenderung bening dan bukan putih susu.

Telur yang tidak dibuahi (Gambar 4a) sangat mudah untuk pecah berbeda dengan telur yang dibuahi dan sangat sulit untuk melihat ruang perivitelline, yaitu ruang antara korion dan kuning telur (Kinoshita et al., 2009). Warna telur yang tidak dibuahi cenderung bening dan bukan putih susu.

Tahap perkembangan embriogenesis ikan $O$. woworae terdiri dari 5 fase yaitu fase pembelahan sel (Gambar 2b), fase morula (Gambar 2c), fase blastula (Gambar 2d), fase gastrula (Gambar 2e), fase organogenesis (Gambar 2f dan 2g) dan telur menetas dan menjadi larva (Gambar 6). Ukuran larva ikan $O$. woworae yang baru menetas yairu 4,25-5,03 mm $(4,63 \pm 0,28 \mathrm{~mm})$. Ukuran larva ikan $O$. woworae berumur 7 hari yaitu 5,30-6,33 $(5,91 \pm 0,39 \mathrm{~mm})$. 


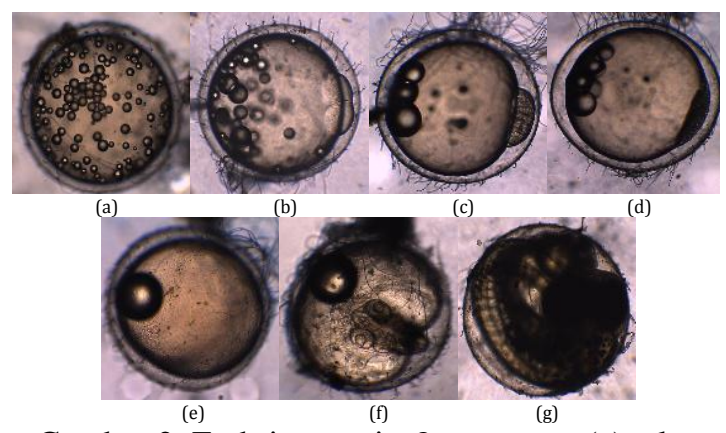

Gambar 2. Embriogenesis O. woworae (a) telur terfertilisasi, (b) pembelahan sel,(c) morula, (d) blastula, (e) gastrula, (f) organogenesis awal, (g) organogenesis akhir

Selama pengamatan terlihat butiran minyak menyebar saat fase awal telur setelah dibuahi dan memiliki ukuran yang bervariasi. Butiran minyak akan terkumpul pada salah satu kutub dan blastomer akan terus berkembang dan terkumpul pada sisi yang berlawanan (Puspitasari \& Suratno, 2017). Butiran minyak akan berkumpul di kutub vegetal (Gambar 4c) dan sel akan berkembang di kutub animal (Gambar 4d).

Tabel 1. Waktu embriogenesis per fase

\begin{tabular}{|c|c|c|c|c|}
\hline \multirow{2}{*}{ Stadia } & \multicolumn{4}{|c|}{ Waktu perkembangan } \\
\hline & O ppt & $\begin{array}{l}2-4 \\
\text { ppt }\end{array}$ & $\begin{array}{l}4-8 \\
\text { ppt }\end{array}$ & $\begin{array}{l}10-12 \\
\text { ppt }\end{array}$ \\
\hline Cleavage & $1 ’ 20 "$ & $1 ’ 20 "$ & 1'20”' & 1'20”' \\
\hline Morula & 5'10" & $5,10^{\prime \prime}$ & 5'10” & $5,10 ”$ \\
\hline Blastula & 11'9”' & $10 ’ 38^{\prime \prime}$ & $10 ’ 25 ”$ & $10^{\prime}$ \\
\hline Gastrula & $14 ' 26 "$ & $14^{\prime} 28^{\prime \prime}$ & $14 ' 30 "$ & 14'1"' \\
\hline $\begin{array}{l}\text { Organogen } \\
\text { esis* }\end{array}$ & $\begin{array}{c}1 \mathrm{H} \\
7^{\prime} 52^{\prime \prime}\end{array}$ & $\begin{array}{c}1 \mathrm{H} \\
7^{\prime} 12^{\prime \prime}\end{array}$ & $\begin{array}{c}1 \mathrm{H} \\
8 ’ 36^{\prime \prime}\end{array}$ & $\begin{array}{c}1 \mathrm{H} \\
8 ' 16^{\prime \prime}\end{array}$ \\
\hline $\begin{array}{l}\text { Organogen } \\
\text { esis** }\end{array}$ & $\begin{array}{l}4 \mathrm{H} \\
15 "\end{array}$ & $\begin{array}{c}3 \mathrm{H} \\
20 ’ 38^{\prime}\end{array}$ & $\begin{array}{c}4 \mathrm{H} \\
4^{\prime} 21 ”\end{array}$ & $\begin{array}{c}4 \mathrm{H} \\
10^{\prime} 6^{\prime \prime}\end{array}$ \\
\hline Menetas & $\begin{array}{c}7 \mathrm{H} \\
19^{\prime} 45^{\prime}\end{array}$ & $\begin{array}{c}7 \mathrm{H} \\
14^{\prime} 20 "\end{array}$ & $\begin{array}{c}7 \mathrm{H} \\
22 ' 12 "\end{array}$ & $\begin{array}{c}8 \mathrm{H} \\
1 ' 16 "\end{array}$ \\
\hline
\end{tabular}

H: hari, ': jam, ": menit, *: awal **: akhir
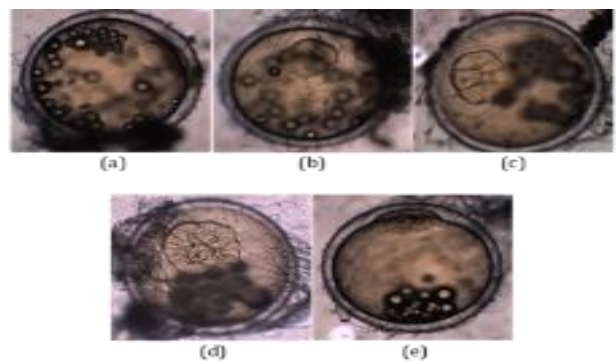

Gambar 3. Fase pembelahan sel $O$. woworae (a) 2 sel, (b) 4 sel, (c) 8 sel, (d) $16 \mathrm{sel}$, (e) $32 \mathrm{sel}$

Fase pembelahan sel terbagi menjadi beberapa fase yaitu fase pembelahan 2 sel, (Gambar 3a), fase pembelahan 4 sel (Gambar 3b), fase pembelahan 8 sel (Gambar 3c), fase pembelahan 16 sel (Gambar 3d) dan fase pembelahan 32 sel (Gambar 32). Fase pembelahan sel merupakan proses perkembangan embrio secara cepat yang membelah menjadi 2 sel hingga 32 sel (Diana et al., 2017). Waktu perkembangan dari telur yang terfertilisasi ke fase pembelahan sel terjadi 1 jam 20 menit. Waktu perkembangan fase pembelahan empat sel terjadi 2 jam 20 menit. Waktu perkembangan fase pembelahan delapan sel terjadi 3 jam setelah telur terfertilisasi. Waktu perkembangan fase pembelahan enam belas sel terjadi 3 jam 40 menit setelah terfertilisasi. Waktu perkembangan fase pembelahan tiga puluh dua sel terjadi 4 jam 30 menit setelah telur terfertilisasi.

Fase perkembangan embrio $O$. woworae selanjutnya adalah fase morula (Gambar 2c). Fase morula terjadi 5 jam 10 menit setelah telur terfertilisasi. Morula merupakan fase pembelahan sel yang terjadi setelah sel berjumlah 32 sel dan berakhir bila blastomer sudah menghasilkan sejumlah sel yang berukuran sama tetapi ukurannya lebih kecil (Gusrina, 2014). Blastomer tersebut memadat sehingga akan membentuk blastodisc kecil (Redha et al., 2014).

Fase berikutnya adalah fase blastula (Gambar 2d). Fase blastula merupakan fase yang diawali dengan semakin banyak sel blastomer. Fase blastula akhir blastodisc semakin mendatar (Rahardjo et al., 2011). Fase blastula pada perlakuan 0 ppt terjadi 11 jam 9 menit setelah telur terfertilisasi. Fase blastula pada perlakuan 24 ppt terjadi 10 jam 28 menit setelah telur terfertilisasi. Fase blastula pada perlakuan 6-8 ppt terjadi 10 jam 25 menit setelah telur terfertilisasi. Fase blastula pada perlakuan $10-12$ ppt terjadi 10 jam setelah telur terfertilisasi. Hasil dari penelitian ini menunjukkan bahwa perlakuan 1012 ppt lebih cepat dibandingkan dengan perlakuan lainnya.

Fase gastrula (Gambar 2e) terjadi ketika sel bakal organ yang telah terbentuk mengalami perkembangan lebih lanjut. Pada fase ini lekukan tubuh semakin nyata dan terlihat (Diana et al., 2017). Fase gastrula pada perlakuan 0 ppt terjadi 14 jam 26 menit setelah telur terfertilisasi. Fase gastrula pada perlakuan 2-4 ppt terjadi 14 jam 28 menit setelah telur terfertilisasi. Fase gastrula pada perlakuan 6-8 ppt terjadi 14 jam 30 menit setelah telur terfertilisasi. Fase gastrula pada perlakuan 10-12 ppt terjadi 14 jam 1 menit setelah telur terfertilisasi. Hasil dari penelitian ini menunjukkan bahwa perlakuan 10-12 ppt lebih cepat dibandingkan dengan perlakuan lainnya. 
Pada fase ini, jaringan luar embrio terus berkembang mengelilingi kuning telur. Fase gastrula berakhir apabila sudah terdapat bakal ikan didalam telur. Akhir proses gastrula menandai awal dimulai pembentukan organorgan (Redha et al., 2014).

Fase organogenesis adalah fase terakhir proses embriogenesis. Pada fase ini ditunjukkan dengan terbentuknya organ-organ tubuh yang ditandai dengan adanya bakal mata yang menyerupai bintik kecil (Annur et al., 2016). Fase organogenesis awal merupakan fase awal terjadinya organogenesis pada perkembangan embrio, pada fase ini bakal tubuh dan bakal mata sudah terlihat. Fase organogenesis awal pada perlakuan 0 ppt terjadi 1 hari 7 jam 52 menit atau 31 jam 52 menit setelah telur terfertilisasi. Fase organogenesis awal pada perlakuan 2-4 ppt terjadi 1 hari 7 jam 12 menit atau 31 jam 12 menit setelah telur terfertilisasi. Fase organogenesis awal pada perlakuan 6-8 ppt terjadi 1 hari 8 jam 36 menit atau 32 jam 36 menit setelah telur terfertilisasi. Fase organogenesis awal pada perlakuan 10-12 ppt terjadi 1 hari 8 jam 16 menit atau 32 jam 16 menit setelah telur terfertilisasi. Hasil dari penelitian ini menunjukkan bahwa pada perlakuan 2-4 ppt lebih cepat dibandingkan dengan perlakuan lainnya.

Perubahan yang sangat terlihat saat fase organogenesis adalah perkembangan mata, tubuh, detak jantung dan munculnya pigmentasi. Fase organogenesis awal ditandai dengan adanya bakal tubuh di dalam telur. Fase organogenesis awal ditandai dengan kepala dan ekor telah dapat dibedakan dan rongga mata mulai terbentuk (Herjayanto et al., 2017). Perubahan bintik mata dapat dilihat dari perubahan warna (Mubarokah et al., 2014). Awal terbentuk bintik mata, bakal mata terlihat dan belum memiliki warna. Mengikuti dengan perkembangan embrio, bakal mata akan semakin menghitam dan semakin sempurna. Fase organogenesis saat jantung berdetak terjadi pada 1 hari 12 jam 11 menit atau 36 jam 11 menit setelah telur terfertilisasi. Semakin berkembang embrio semakin cepat detak jantung yang dihasilkan. Fase organogenesis saat pigmentasi tubuh terjadi 3 hari 3 jam 39 menit atau 75 jam 39 menit setelah telur terfertilisasi. Embrio terus menyempurnakan organ-organnya dilanjutkan dengan aliran sirkulasi darah mulai mengalir dan berubah warna menjadi kemerahan, detak jantung berwarna kemerahan dan embrio akan mulai bergerak.

Fase organogenesis akhir merupakan fase penyempurnaan embrio menjadi bentuk individu.
Fase ini merupakan fase terakhir sebelum larva menetas. Fase organogenesis akhir pada perlakuan 0 ppt terjadi 4 hari 15 menit atau 96 jam 15 menit setelah telur terfertilisasi. Fase organogenesis akhir pada perlakuan 2-4 ppt terjadi 3 hari 20 jam 38 menit atau 92 jam 38 menit setelah telur terfertilisasi. Fase organogenesis akhir pada perlakuan 6-8 ppt terjadi pada 4 hari 4 jam 21 menit atau 100 jam 21 menit setelah telur terfertilisasi. Fase organogenesis akhir pada perlakuan 10-12 ppt terjadi 4 hari 10 jam 6 menit atau 106 jam 6 menit setelah telur terfertilisasi. Dari hasil embriologi dapat dilihat bahwa adanya respon waktu berbeda yang dihasilkan. Sama seperti pendapat Mustahal et al., (2019) bahwa kemampuan telur ikan yang berbeda pada fase embriogenesis terjadi akibat adanya perbedaan kemampuan adaptasi dalam menerima salinitas media inkubasi yang diberikan. Hasil dari penelitian ini menunjukkan bahwa perlakuan 2-4 ppt dianggap mendekati isoosmotik terhadap telur O.woworae, tekanan osmotik dalam telur yang ideal akan meminimalkan energi sehingga dapat mempercepat proses penetasan. Ini didukung oleh Mubarokah et al., (2014), apabila terjadi perbedaan antara osmotik lingkungan dengan osmotik di dalam telur maka hal tersebut akan memperlambat proses penetasan yang diakibatkan telur membutuhkan energi yang besar untuk mempertahankan tekanan osmotiknya.

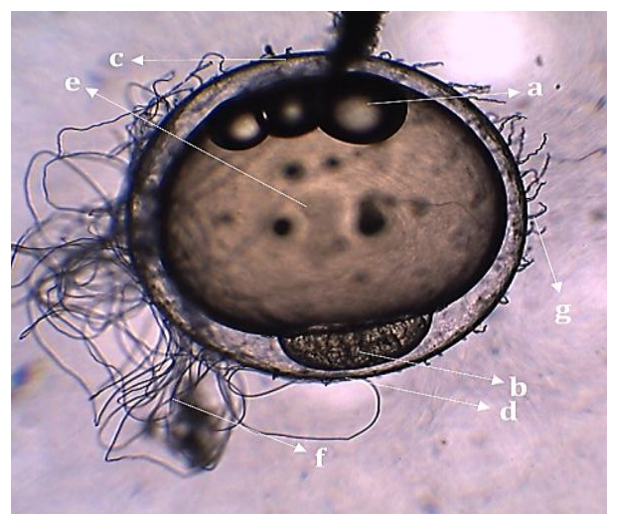

Gambar 4. Stadia morula (a) butiran minyak, (b) blastomer (c) kutub vegetal, (d) kutub animal, (e) kuning telur (egg yolk), (f) attaching filament, (g) non-attaching filament

Butiran minyak menyebar saat telur baru terfertilisasi (Gambar 2a). Seiring perkembangan embrio, butiran minyak akan berkumpul menjadi satu (Gambar 2e). Pada fase gastrula butiran minyak telur O.woworae akan berubah menjadi 
satu, namun pemberian salinitas yang tidak isoosmotik mempercepat proses perkembangan embrio sehingga proses perkembangan terjadi saat butiran minyak belum menjadi satu (Gambar 5b). Blastomer (Gambar 4b) terus berkembang seiring dengan perkembangan embrio yang akan berkembang menjadi bakal ikan. Kuning telur merupakan sumber makanan bagi larva yang menetas. Attaching fillament (Gambar 4f) merupakan filamen-filamen yang berfungsi untuk menempelkan telur pada sustrat. Nonattaching fillament (Gambar $4 \mathrm{~g}$ ) adalah filamenfilemen halus yang tumbuh dipermukaan telur.

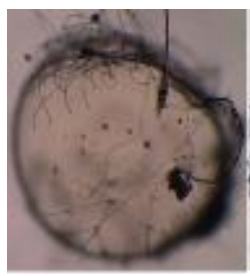

[a]

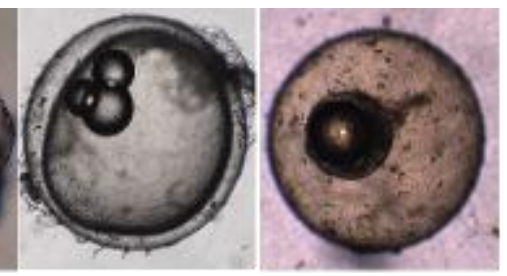

(b) (c)
Gambar 5. Telur (a) telur yang tidak terfertilisasi, (b) gastrula pada perlakuan 10-12 ppt,

(c) telur mengkerut

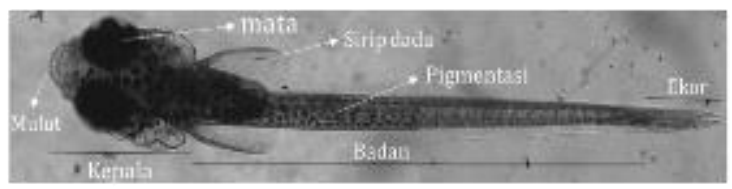

(a)

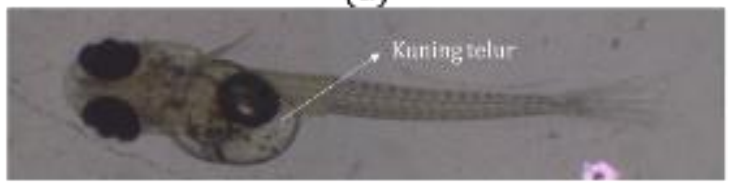

(b)

Gambar 6. Larva (a) larva tampak atas,

(b) larva tampak bawah

Kuning telur dapat bertahan hingga satu minggu pada larva kondisi inkubasi media normal, namun pada larva kondisi media yang diberi perlakuan salinitas cenderung lebih cepat habis. Larva yang membawa cadangan makanan untuk perkembangan organ tubuh disebut endogenous feeding (Mariska et al., 2013). Tingkah laku larva dengan media normal pun berbeda dengan media yang diberi perlakuan. Larva pada media normal cenderung aktif dan berada di atas atau di tengah wadah. Sedangkan larva ikan dengan media perlakuan cenderung pasif dan berada di tengah dan di bawah wadah. Larva diberi makan 5 hari setelah menetas, larva diberi pakan suspensi kuning telur karena bukaan mulut larva masih terlalu kecil untuk diberikan Daphnia sp., Moina sp. atau Artemia sp. Mata larva memiliki dua warna yang berbeda saat diberi cahaya, mata hitam seperti menyala kebiruan dan mata hitam biasa. Jantan memiliki warna mata biru dan betina memiliki mata coklat pada ikan O. matanensis (Fahmi et al., 2019).

\section{Lama Waktu Penetasan}

Tabel 2. Waktu penetasan telur ikan $O$. woworae

\begin{tabular}{|c|c|}
\hline Perlakuan & Waktu \\
\hline $\mathrm{A}(0 \mathrm{ppt})$ & 7 H 19' 45', \\
\hline $\mathrm{B}(2-4 \mathrm{ppt})$ & 7H 14'20', \\
\hline $\mathrm{C}(6-8 \mathrm{ppt})$ & $7 \mathrm{H} \mathrm{22}$ ' 12'” \\
\hline $\mathrm{D}(10-12 \mathrm{ppt})$ & $8 \mathrm{H} \mathrm{1}{ }^{\prime} 16^{\prime \prime}$ \\
\hline
\end{tabular}

Keterangan: H: hari, ':jam, "': menit

Dari hasil pengamatan Tabel 2 menunjukkan bahwa waktu penetasan telur berbeda pada setiap perlakuan salinitas yang diberikan. Perlakuan B lebih cepat dibandingkan waktu penetasan pada perlakuan kontrol yaitu 0 ppt yaitu selama 7 hari 19 jam 45 menit atau 187 jam 45 menit. Hasil ini menunjukkan bahwa perlakuan 2-4 ppt merupakan perlakuan yang diduga mendekati salinitas isoosmotik.

Waktu penetasan ikan medaka atau $O$. latipes 8- 10 hari, embrio yang diinkubasi pada suhu $26^{\circ} \mathrm{C}$ biasanya keluar dari korion telur atau menetas dalam waktu 10 hari (Kinoshita et al., 2009). Waktu penetasan O. javanicus 11 hari pada perlakuan air tawar dan 9 hari pada perlakuan salinitas 15 ppt dan 30 ppt (Puspitasari $\&$ Suratno, 2017). O. javanicus yang diinkubasi di laboratorium mulai menetas pada hari ke-11 setelah telur terfertilisasi dan memiliki puncak penetasan pada hari ke-13 setelah telur terfertilisasi (Herjayanto et al., 2019). Ikan $O$. woworae memiliki waktu penetasan 9-12 hari pada kondisi air tawar dan pada suhu yang fluktuatif. Pengaturan salinitas terbukti dapat mempercepat waktu dari penetasan.

Cepatnya waktu penetasan pada perlakuan 2-4 ppt disebabkan karena kondisi salinitas yang optimum terhadap telur sehingga meminimalkan energi osmoregulasi telur. Aktivitas embrio didalam telur juga dipengaruhi oleh salinitas. Salinitas yang optimum juga mempengaruhi aktivitas dari embrio. Mubarokah et al., (2014), salinitas meningkatkan kandungan sel klorid 
sehingga akan mengontrol proses osmoregulasi dan mempengaruhi lama waktu penetasan ikan. Selain itu sel klorid dapat mengentalkan cairan didalam telur sehingga energi untuk aktivitas osmoregulasi dan proses-proses lain dapat diminimalkan dan sisa energi dapat digunakan untuk pertumbuhan telur ikan. Pemberian salinitas menjadi salah satu faktor lingkungan yang dapat mempengaruhi lama waktu penetasan telur. Penetasan terjadi lebih cepat bila embrio dalam cangkang lebih aktif bergerak karena salinitas merupakan salah satu faktor luar yang mempengaruhi aktivitas embrio (Hadid et al., 2014).

\section{Derajat Tetas Telur}

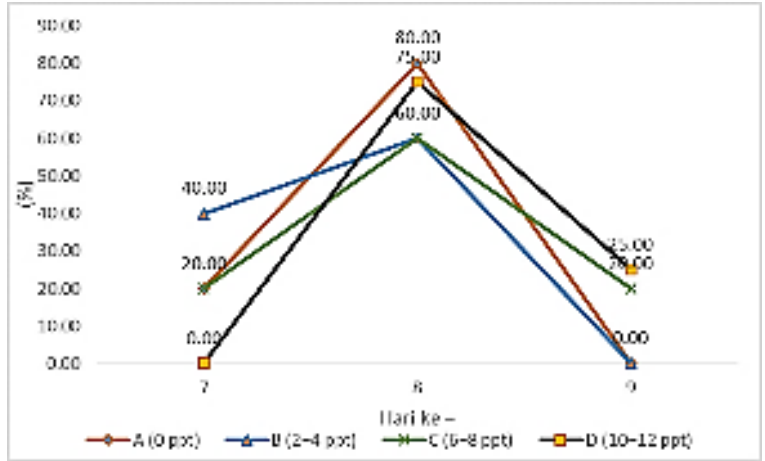

Gambar 7. Grafik derajat tetas telur per hari

Dari grafik di atas menunjukkan bahwa derajat tetas telur per hari berbeda pada setiap perlakuan salinitas yang diberikan. Telur $O$. woworae mulai menetas pada hari ke-7 setelah fertilisasi telur, memiliki puncak penetasan pada hari ke-8 setelah telur terfertilisasi dan penetasan berakhir pada hari ke-9 setelah telur terfertilisasi. Perlakuan 0 ppt menetas pada hari ke-7 sebesar $20 \%$ dan menetas pada hari ke-8 sebesar $80 \%$. Perlakuan 2-4 ppt menetas $40 \%$ pada hari ke-7 dan menetas $60 \%$ di hari ke-8. Perlakuan 6-8 ppt menetas pada hari ke-7 sebesar $20 \%$ dan menetas pada hari ke-8 sebesar $60 \%$ dan pada hari ke-9 menetas sebesar 20\%. Perlakuan 10-12 ppt menetas pada hari ke- 8 sebesar $75 \%$ dan pada hari ke-9 sebesar $25 \%$.

Perlakuan 2-4 ppt menunjukkan bahwa telur menetas lebih awal dan lebih cepat dibandingkan dengan perlakuan lain. Pemberian salinitas mengubah konsentrasi cairan didalam dan diluar telur menjadi semakin besar atau semakin kecil hal ini tergantung kemampuan adaptasi telur terhadap lingkungan dan kondisi cairan yang berada didalam telur (Mustahal et al., 2019). Salinitas juga dapat mempengaruhi aktivitas dari embrio didalam telur. Salinitas yang optimum juga mempengaruhi aktivitas dari embrio. Ini didukung oleh penelitian Heltonika, (2014), salinitas memberikan pengaruh yang mendukung proses penetasan telur. Telur yang isoosmotik akan membantu perkembangan embrio dan ketahanan telur.

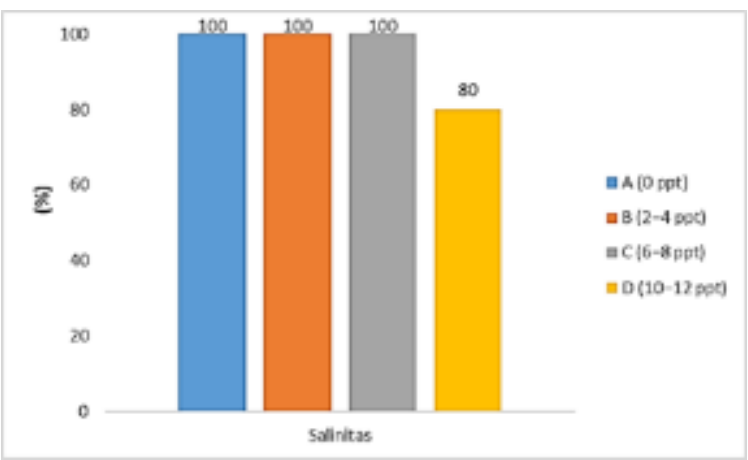

Gambar 8. Grafik derajat tetas telur

Dari grafik diatas menunjukkan bahwa derajat tetas telur pada setiap perlakuan salinitas yang diberikan tidak berpengaruh. Perlakuan 0 ppt yaitu $100 \%$ perlakuan 2-4 ppt yaitu $100 \%$ dan perlakuan 6-8 ppt yaitu $100 \%$. Perlakuan $0 \mathrm{ppt}$, 2-4 ppt dan 6-8 ppt memiliki presentase hatching rate yang sama. Pada perlakuan 10-12 ppt memiliki derajat tetas telur $80 \pm 12,58 \%$ karena ditemukan telur yang embrionya telah mati mengkerut (Gambar 4c). Hal ini terjadi karena telur tidak dapat metoleransi salinitas lingkungan yang diberikan. Ini didukung oleh Rahardjo et al., (2011), bila telur ikan air tawar dimasukkan dalam media salinitas yang tak dapat ditoleransinya maka telur akan mengerut karena air tertarik keluar dan akhirnya telur akan mati.

\section{Kualitas Air}

Informasi kualitas air untuk ikan $O$. woworae sendiri belum banyak ditemukan. Dari penelitian ini menunjukkan kualitas air untuk induk ikan $O$. woworae, DO yang terdapat yaitu $6,9 \mathrm{mg} / \mathrm{L}$ dan untuk telur $4-6,5 \mathrm{mg} / \mathrm{L}$. DO ini dinilai cukup untuk telur dan induk ikan $O$. woworae karena diketahui ikan ini sendiri dapat hidup tanpa pemberian aerasi dan habitat asli ikan ini adalah di sungai dan cenderung di mata air (Yamahira et al., 2016). Pada penelitian ini $\mathrm{pH}$ untuk induk 
ikan 7,1 dan pada inkubasi penetasan telur berkisar 7,1-8,9. $\mathrm{pH}$ cenderung tinggi karena adanya pemberian salinitas. Suhu yang digunakan untuk pemijahan ikan tidak diberi termostat dan suhu dibiarkan fluktuatif mengikuti kondisi lingkungan. Suhu untuk pemijahan ikan yaitu $24-28^{\circ} \mathrm{C}$. Suhu yang digunakan pada penelitian ini adalah $29-30^{\circ} \mathrm{C}$ supaya pengaruh suhu tidak memberi dampak pada telur karena penelitian ini ingin berfokus pada pengaruh salinitas terhadap telur. Kualitas air dari penelitian ini tidak bisa dibandingkan karena belum adanya informasi tentang kualitas air untuk budidaya atau untuk pemeliharaan ikan O. woworae. Parameter salinitas yang digunakan pada penelitian ini menunjukkan bahwa $O$. woworae dapat hidup pada salinitas hingga 1012 ppt dan sesuai dengan penelitian Juo et al., (2016).

Tabel 3. Kualitas air

\begin{tabular}{|c|c|c|}
\hline \multirow{2}{*}{ Parameter } & \multicolumn{2}{|c|}{ Nilai } \\
\cline { 2 - 3 } & $\begin{array}{c}\text { Pemijahan } \\
\text { ikan }\end{array}$ & $\begin{array}{c}\text { Penetasan } \\
\text { telur }\end{array}$ \\
\hline $\begin{array}{c}\mathrm{DO} \\
(\mathrm{mg} / \mathrm{L})\end{array}$ & 6,9 & $4,0-6,5$ \\
\hline $\mathrm{pH}$ & 7,1 & $7,1-8,9$ \\
\hline Suhu $\left({ }^{\circ} \mathrm{C}\right)$ & $24,0-28,0$ & $29,0-30,0$ \\
\hline
\end{tabular}

\section{Kesimpulan}

Telur ikan $O$. woworae dapat berkembang dan menetas pada salinitas 0 hingga 12 ppt. Salinitas yang optimal bagi penetasan telur $O$. woworae adalah salinitas 2-4 ppt yang dapat mempercepat lama waktu penetasan dan menghasilkan derajat tetas sebesar $100 \%$.

\section{Ucapan terima kasih}

Terima kasih kepada Program Studi Ilmu Perikanan Universitas Sultan Ageng Tirtayasa, Laboratorium Budidaya Perairan Universitas Sultan Ageng Tirtayasa, Banten. Penulis juga ucapkan terimakasih kepada saudari Nisa Nafiyanti dan tim riset $O$. woworae yang telah membantu penelitian ini.

\section{Referensi}

Annur., Madinawati., Mangitung, S.F., \& Rusaini. (2016). Embriogenesis Ikan Cupang (Betta splendens). Jurnal Agrisains. 17(3):137-140. DOI: https://www.researchgate.net/publication/ $\underline{324721519}$

Dahruddin, H. (2012). Ikan Padi (Oryzias sp.) dari Sulawesi. Fauna Indonesia. 11(2):2832.

DOI:

https://mazoin.files.wordpress.com

Diana, F., Rahmita, S., \& Diansyah, S. (2017). Pengendalian Jamur Saprolegnia sp. pada Telur Ikan Tawes (Puntius javanicus) Menggunakan Ekstrak Daun Bunga Tahi Ayam (Tagetes erecta L). Jurnal Perikanan Tropis. 4(2): 101:113. DOI: https://doi.org/10.35308/jpt.v4i2.784

Effendi, I. (2012). Pengantar Akuakultur. Jakarta: Penebar Swadaya. 188 hal

Fahmi, M.R., Prasetyo, A.B., \& Vidiakusuma, R. (2014). Potensi Ikan Medaka (Oryzias woworae, O. javanicus, O. frofudicola) Sebagai Ikan Hias dan Ikan Model. Editor Raharjo MF, Zafid A, Hadiaty RK, Manangkali E, Hadie W, Haryono, Supriyono E. Prosiding Seminar Nasional Ikan ke-8. 227-233.

Fahmi, U., Andriani, I., Salmah, S., Hatta, T.H., Omar, S.B.A., \& Sari, D.K. (2019). Histopathology of Liver and Intestine of Pangkilan Bare Fish (Oryzias matanensis) Polluted by Nickel and Iron in Lake Matano, South Sulawesi. The 2nd International Symposium on Marine Science and Fisheries. IOP Conference Series:Earth and Enviromental Science. 370:1-7. DOI: https://doi:10.1088/17551315/370/1/012078

Gusrina (2014). Genetika dan Reproduksi Ikan. Yogyakarta: CV Budi Utama. 254 hal.

Hadiaty, R.K. (2018). Status Taksonomi Ikhtiofauna Endemik Perairan Tawar Sulawesi. Jurnal Ikhtiologi Indonesia. 18(2)175-190.

DOI: https://doi.org/10.32491/jii.v18i2.428 
Hadid, Y., Syaifudin, M., \& Amin, M. (2014). Pengaruh Salinitas Terhadap Daya Tetas Telur Ikan Baung (Hemibagrus nemurus Blkr.). Jurnal Akuakultur Rawa Indonesia. 2(1):78-92.

DOI: https://doi.org/10.36706/jari.v2i1.2056

Heltonika, B. (2014). Pengaruh Salinitas Terhadap Penetasan Telur Ikan Jambal Siam (Pangasius hypohthalmus). Jurnal Akuakultur Rawa Indonesia. 2(1):13-23. DOI:https://doi.org/10.36706/jari.v2i1.19 $\underline{59}$

Herjayanto, M., Carman, O., \& Soelistyomati, D.T. (2016). Tingkah Laku Memijah, Potensi Reproduksi Ikan Betina dan Optimasi Teknik Pemijahan Ikan Pelangi Iriatherina werneri Meinken 1974. Jurnal Akuatika Indonesia. 16(2):171-183. DOI: https://doi.org/10.32491/jii.v16i2.39

Herjayanto, M., Carman, O., \& Soelistyomati, D.T. (2017). Embriogenesis, Perkembangan Larva dan Vibialitas Reproduksi Ikan Pelangi Iriatherina werneri Meinken, 1974 Pada Kondisi Laboratorium. Jurnal Akuakultur Indonesia. 2(1) 1-10. DOI: https://doi.org/10.24198/jaki.v2i1.23389

Herjayanto, M., Mauliddina, A.M., Widiyawan, E.R., Prasetyo, N.A., Agung, LA., Magfira., \& Gani, A. (2019). Studi Awal Pemeliharaan Oryzias sp. Asal Pulau Tunda Indonesia pada Kondisi Laboratorium. Musamus Fisheries and Marine Journal. 2(1):24-34. DOI: https://doi.org/10.35724/mfmj.v2i1.1872

Hutagalung, J., Alawi, A., \& Sukendi. (2017). Pengaruh Suhu dan Oksigen Terhadap Penetasan Telur dan Kelulusan Hidup Awal Larva Ikan Pawas (Osteochilus hasselti C.V.). Jurnal Fakultas Perikanan dan Ilmu Kelautan. 4(1):1-13. DOI: https://jom.umri.ac.id/index.php/JOMFA PERIKA/article/view/13196

Juo, J.J., Kang, C.K., Yang, W.K., Yang, S.Y., \& Lee, T.H. (2016). A Stenohaline Medaka,
Oryzias woworae, Increase Expression of Gill Na+, K+, 2Cl- Contransporter 1 to Tolerate Osmotic Stress. Zoological Science. $\quad 33$ : 414-425. DOI: https://doi.org/10.2108/zs150157

Kinoshita, M., Murata, K., Naruse, K., \& Tanaka, M. (2009). Medaka: Biology, Management and Experimental Protocols. Ames. Willy-Blackwell. 447 p.

Mandagi, I.F., Mokadongan, D.F., Tanaka, R., \& Yamahira, K. (2018). A New Riverine Ricefish of the Genus Oryzias (Beloniformes, Adrianichtyidae) from Malili, Central Sulawesi, Indonesia. Copeia 106. No. 2: 297-304. DOI: https://doi.org/10.1643/Cl-17-704

Mariska, A., Muslim., \& Fitriani, M. (2013). Laju Penyerapan Kuning Telur Tambakan (Helostoma temminckii C.V) dengan Suhu Inkubasi Berbeda. Jurnal Akuakultur Rawa Indonesia. 1(1): 34-45. DOI: https://doi.org/10.36706/jari.v1i1.1777

Mubarokah, D., Tarsim., \& Kadarini, T. (2014). Embriogenesis dan Daya Tetas Telur Ikan Pelangi (Melanotaenia parva) pada Salinitas yang Berbeda. Jurnal Ilmu Perikanan dan Sumberdaya Perairan. 2(2): 157-162. DOI: https://jurnal.fp.unila.ac.id/index.php/JPB P/article/view/278/274

Mustahal., Hasibuan, Z.H., Syamsunarno, M.B., \& Nugraha, K.A. (2019). Different of Saline Embriogenesis and Eggs Hatching Rate of the Giant Gouramy (Osphronemus gouramy). ICFAES. 348:1-7. DOI: https://doi.org/10.1088/17551315/348/1/012044

Mustofa, A. (2020). Pengolahan Kualitas Air untuk Akuakultur. Jepara: UNISNU press. 133 hal.

Nani, M., Abidin, Z., \& Setyono, B.D.H. (2015). Efektivitas Sistem Pengangkutan Ikan Nila (Oreochromis sp) Ukuran Konsumsi Menggunakan Sistem Basah, Semi Basah dan Kering. Jurnal Akuakultur Rawa 
Indonesia. $\quad 3(2): \quad 84-90 . \quad$ DOI: https://doi.org/10.36706/jari.v3i2.4444

Parenti, L.R. (2008). A Phylogenetic Analysis and Taxonomic Revision of Ricefish, Oryzias and Relative (Beloniformes, Adrianichthydae). Zoological Journal of Linnean Society. 154: 494-610. DOI: https://doi.org/10.1111/j.1096$\underline{3642.2008 .00417 . x}$

Parenti, L.R., Hadiaty, R.K., Lumbantobing, D., \& Herder, F. (2013). Two New Ricefish of the Genus Oryzias (Atherinomorpha: Beloniformes: Adrianichthyidae) Augment the Endemic Freshwater Fish Fauna of Southeastern Sulawesi, Indonesia. Copeia 2013. No. 3: 403-414. DOI: https://doi.org/10.1643/Cl-12-114

Puspitasari, R., \& Suratno. (2017). Studi Awal Perkembangan Larva Oryzias javanicus di Indonesia. Jurnal Ilmu dan Teknologi Kelautan Tropis. 9(1): 105-112. DOI: https://itk.fpik.ipb.ac.id/ej_itkt91

Rahardjo, M.F., Sjafei, D.S., Affandi, R., Sulistiono, \& Hutabarat, J. (2011). Iktiology. Bandung. IKAPI 396 hal.

Redha, A.R., Raharjo, E.I., \& Hasan, H. (2014). Pengaruh Suhu yang Berbeda Terhadap Perkembangan Embrio dan Daya Tetas Telur Ikan Kelabau (Osteochilus melanopleura). Jurnal Ruaya. 4(1):1 DOI:https://doi.org/10.29406/rya.v4i2.48 $\underline{1 .}$

Roberts, T.R. (1998). Systematic Observations on Tropical Asian Medakas or Ricefishes of the Genus Oryzias, with Descriptions of Four New Species. Ichthyological Research. 45(3): 213-224. DOI: https://doi.org/10.1007/bf02673919

Sumarmin, R. (2016). Perkembangan Hewan. Jakarta: Kencana. 281 hal.

Yamahira, K., Mochida, K., Fujimoto, S., Mokodongan, D.F., Montenegro, J., Kaito, T., Ishikawa, A., Kitano, J., Sue, T., Mulis., Hadiaty, R.K., Mandagi, I.F., ....
Masengi, K.W.A. (2016). New Localities of the Oryzias woworae Species Group (Adrianichthyidae) in Sulawesi Tenggara. Jurnal Ikhtiologi Indonesia. 16(2): 125131.

DOI: 